\begin{tabular}{|c|c|c|} 
PRODUCTIVE PROCESSES BASED ON 3D PRINTING VERSUS \\
CONVENTIONAL METHODOLOGIES: A COMPARATIVE ANALYSIS IN \\
THE CONSTRUCTION SECTOR \\
Ingeniería e Industria \\
RESEARCH ARTICLE
\end{tabular}

\title{
PRODUCTIVE PROCESSES BASED ON 3D PRINTING VERSUS CONVENTIONAL METHODOLOGIES: A COMPARATIVE ANALYSIS IN THE CONSTRUCTION SECTOR
}

\author{
José Manuel Mesa Fernández¹, Juan Carlos Piquero Camblor², Marina Díaz Piloñeta1', Henar Morán Palacios ${ }^{1}$ \\ 1 Universidad de Oviedo. Área de Proyectos de Ingeniería. Calle Independencia, $13-33004$ Oviedo. Asturias Tfno.: +34 98510 \\ 42 72. immesa@uniovi.es \\ 2 IDONIAL, Parque Cientifico Tecnológico de Gijón, Zona INTRA. Avda. Jardín Botánico, 134533203 Gijón, Asturias \\ Received: 14/Nov/2020 --Reviewing: 14/Nov/2020-- Accepted: 15/Jan/2020 - DOl: http://dx.doi.org/10.6036/9504
}

\begin{abstract}
:
Although the production methodologies and technologies used in the construction sector have evolved over time, much of the work is still done using techniques that can be considered less evolved than those used in other industrial sectors where robotics and other advanced manufacturing technologies are much more implemented.

In this framework it is presented an analysis regarding the integration of production processes based on $3 D$ printing (additive manufacturing) versus conventional manufacturing methodologies in the construction sector. With this aim in mind, a set of experiments on manufacturing usual construction elements have been conducted, both by conventional methodologies as well as by additive manufacturing. In this way, it is possible to compare variables such as process time, material consumption and quality of each technique, which have an influence on atomization and other aspects such as safety, productivity or environmental impact. The results obtained confirm the potential of additive manufacturing as a fast, safe and efficient construction process.
\end{abstract}

Key Words: construction sector; additive manufacturing; 3D printing; conventional manufacturing; productivity

\section{1.- INTRODUCTION}

The construction industry is a significant part of the economy of any country in terms of Gross Domestic Product (GDP). Despite a long and deep contraction in recent years, this sector represents about $6 \%$ of the GDP of the member states of the European Union [1]. Several studies also establish a direct relationship between the construction industry and economic growth of countries [2]. On the other hand, the construction industry is generally considered a traditional industry, where innovation is rare. [3]. In that sense, despite significant technological advances introduced in recent years in most industrial sectors [3], the productivity ratios in the construction sector remain far behind those established in other sectors [4], [5], and even in some aspects have decreased [6].

Alongside this, the construction industry includes activities and work in most projects involve significant environmental impacts [7], mainly linked to consumption [8] of both material and energy resources. Today, various initiatives are being taken [9] to reduce these impacts on the environment [10] but there is a line of work that defines a common strategy.

Taking all the above into account, it seems clear that the construction sector needs to improve its processes both to increase productivity and to reduce its impact on the environment and the consumption of resources. One of the possible ways may be the use of automated production systems [11],that are more versatile in their management and that optimize the use of materials and accessories.

In this context, this paper presents a comparative analysis of production processes based in 3D printing (additive manufacturing) compared to conventional manufacturing methods in the construction industry. On this purpose, a set of manufacturing experiments of some common construction elements were carried out and are described below. 


\begin{tabular}{|c|c|c|}
\hline $\begin{array}{l}\text { Ingeniería e Industria } \\
\text { Ind }\end{array}$ & $\begin{array}{c}\text { PRODUCTIVE PROCESSES BASED ON 3D PRINTING VERSUS } \\
\text { CONVENTIONAL METHODOLOGIES: A COMPARATIVE ANALYSIS IN } \\
\text { THE CONSTRUCTION SECTOR }\end{array}$ & $\begin{array}{r}\text { CONSTRUCTION } \\
\text { TECHNOLOGY }\end{array}$ \\
\hline RESEARCH ARTICLE & $\begin{array}{l}\text { José Manuel Mesa Fernández, Juan Carlos Piquero Camblor, Marina Díaz } \\
\text { Piloñeta, Henar Morán Palacios }\end{array}$ & Additive Manufacturing \\
\hline
\end{tabular}

\section{1-ADDITIVE MANUFACTURE}

Additive manufacturing is defined as a manufacturing process in which a series of new technologies are used to allow the generation of three-dimensional objects directly from a digital model without the need for molds or other tools. Since a few years, these technologies have broken into different production processes, first as auxiliary systems focused on the development of non-functional prototypes, to the latest advances where parts are manufactured fully operational for such demanding sectors such as aeronautics [12], medicine [13] or automotive [14]. This novel manufacturing method involves a number of advantages in any industrial sector, including construction [15]:

- Reducing the time required for placing on the market for customized products (Time-to-market reduction). This time reduction is because manufacturing processes are direct from CAD 3D file, without specific tools previously made to the customized product, as it happens in many conventional manufacturing processes in which an adaptation is required in product changes.

- Complete freedom and flexibility in product design. Unlike other production processes, additive manufacturing can produce parts with almost any shape and complexity, as it does not have any of the geometric limitations of conventional manufacturing processes.

- Maximum material savings since it is selectively added and not subtracted from a block. For some applications, especially in the metal sector, there are case studies showing that waste produced from raw material is reduced by up to $40 \%$ when using additive manufacturing technologies instead of subtractive (machining) technologies. In addition, between $95 \%$ and $98 \%$ of the unused material can be recycled [16].

- $\quad$ No investment in molds or tools. The part is produced directly from the 3D CAD file. For the first units, thus reducing the investment cost and the time required for production tooling, which eventually affect the manufactured parts, as in conventional processes. All these advantages allow additive manufacturing technologies to be competitive in short and medium series production, where the size of the production will generally depend on the additive manufacturing technology, type of material, complexity of the part geometry and the competitiveness of conventional processes for this case.

Faced with these significant advantages, additive manufacturing also has some drawbacks, many derived from being a technology still under development. Among them it is possible to mention:

- $\quad$ The need to develop new materials or transform existing ones and, therefore, a high cost of raw material.

- The low availability of specific design software for these technologies.

- Difficulty in characterizing the properties of the materials processed by additive manufacturing, as to the additive being a batch process the material properties can be different depending on the manufacturing direction.

- Improvement of surface quality and dimensional precision. Depending on the application and finishing obtained by the additive technology may be necessary to a greater number of post-processing and surface finishing.

\section{2-ADDITIVE MANUFACTURE IN CONSTRUCTION}

At the end of the twentieth century came the first research related to the integration of additive manufacturing processes in the field of construction industry. Authors like Joseph Pegna [17] began researching new building systems based 3D printing. Later, in 2004, Professor Behrokh Khoshnevis of the University of South Carolina built the first wall using 3D printing [18]. He proposed the idea of building individual houses using large-scale 3D printers and named this technology "Contour Crafting". At the same time, Enrico Dini [19] patented a large-scale printing system called D-Shape, an electromechanical system that uses epoxy resin as a printing material and that allows the construction of complex structures. Another prominent group in research on the application of additive manufacturing in construction is the Department of Civil Works and Construction Engineering at Loughborough University (UK). Already in 2007 this group presented an investigation [20] on the possibilities offered by this technology for the construction industry.

In recent years, various works related to the study of 3D printing with construction materials have been carried out [21], which have addressed analyzes of materials in a fresh state [22], the development of specific mortars for additive manufacturing processes [23] as well as theoretical studies on manufacturing methodologies taking into account the complexity of components, the need for supports [24], etc. Currently, as indicated by different authors [25], [26], additive manufacturing applied to construction is still in a research and development phase. Different challenges or problems remain, for example, the proper verification of structural properties through simulation. [27] and the existing limitations for the experimental test of the manufactured elements [3], [28]. This technology 


\begin{tabular}{|c|c|c|} 
PRODUCTIVE PROCESSES BASED ON 3D PRINTING VERSUS \\
CONVENTIONAL METHODOLOGIES: A COMPARATIVE ANALYSIS IN \\
THE CONSTRUCTION SECTOR \\
Ingeniería e Industria
\end{tabular}$\quad \begin{gathered}\text { José Manuel Mesa Fernández, Juan Carlos Piquero Camblor, Marina Díaz } \\
\text { Piloñeta, Henar Morán Palacios }\end{gathered}$

needs to be fully developed and improved as it reflects that large-scale industrial machines are not yet available on the market, nor are appropriate materials or clear business models.

\section{2.- MATERIALS AND METHODS}

As noted above, an experimental development was established to analyze the effect of the introduction in the construction of additive manufacturing technology. Firstly, the most suitable construction elements were selected, which were subsequently manufactured by both conventional formwork methodology and large-scale 3D printing. Subsequently, the comparative analysis allowed studying the productivity linked to the process times, as well as a quality control based on the mechanical behavior of the structures.

The variables that were considered when carrying out the analysis of the construction processes are the following:

- Process time: it was considered as the time from the start of manufacturing until the part is fully finished and available for its application, that is, with fully hardened concrete.

- Materials consumption: both the materials that make up the elements to be manufactured and the different accessory materials required in each case, such as molds or formwork, were considered.

- Staff needed: the number of staff required for the execution of the component manufacturing process was evaluated.

- Structural quality: in this case it was assessed by analyzing the compressive strength.

Although one of the advantages of additive manufacturing is the versatility to produce geometrically complex components, the choice of the elements to study was conditioned by two requirements to fulfill. First, be highly representative of the construction sector and also facilitate the evaluation of manufacturing technologies. Consequently, it was decided to use the two building elements most used, that is, the pillars and beams.

Under these conditions, two standard structural elements were defined with representative dimensions comparable to the components commonly used in construction processes. The dimensions are as follows:

- Square base pillar with $400 \mathrm{~mm} \times 400 \mathrm{~mm}$ side and a height of $900 \mathrm{~mm}$.

- Rectangular base beam $200 \mathrm{~mm} \times 900 \mathrm{~mm}$ with a thickness of $400 \mathrm{~mm}$.

The two construction methods applied to the previously indicated elements are described in the next section.

\section{1.- CONVENTIONAL TECHNOLOGY THROUGH MANUAL FORMWORK}

The conventional beam and pillar construction process (Fig. 1) was developed with the following tasks:

- Manufacture of the mold or formwork element with metal profiles.

- $\quad$ Pouring of concrete inside the obtained formwork.

- Vibration of the previously poured material, to give it homogeneity and thus eliminate possible air accumulations in the form of bubbles.

- $\quad$ Stripping of the mold, after 24 hours.

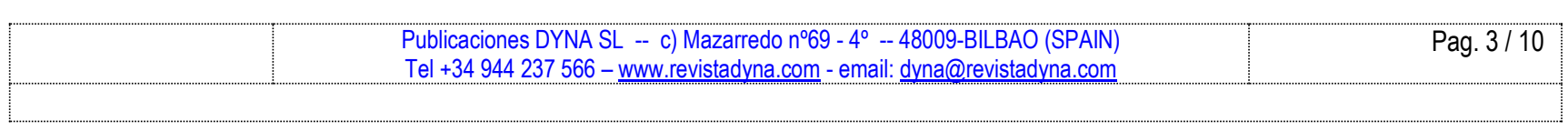




\begin{tabular}{|c|c|c|}
\hline PRODUCTIVE PROCESSES BASED ON 3D PRINTING VERSUS \\
CONVENTIONAL METHODOLOGIES: A COMPARATIVE ANALYSIS IN \\
THE CONSTRUCTION SECTOR \\
Ingeniería e Industria
\end{tabular}$\quad \begin{gathered}\text { José Manuel Mesa Fernández, Juan Carlos Piquero Camblor, Marina Díaz } \\
\text { Piloñeta, Henar Morán Palacios }\end{gathered}$
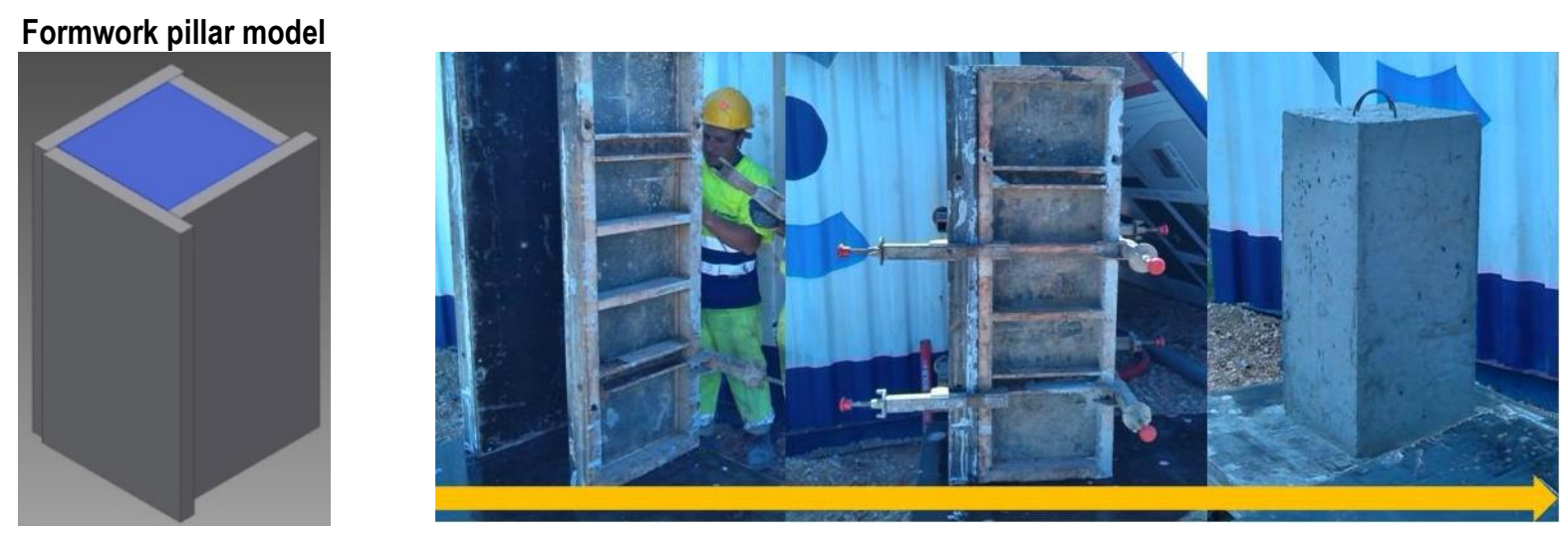

Fig. 1. Making column by conventional method

\section{1.- ADDITIVE MANUFACTURING TECHNOLOGY}

The additive manufacturing system implemented for the development of the construction process was based on a Kuka robotic cell [29]. Different auxiliary systems for material feeding were implemented on that cell, as well as a specific head for concrete printing.

To carry out the manufacturing process using additive manufacturing technologies or 3D printing, it is necessary to previously define the printing paths to be followed by the robotic system, as well as the characteristics that the layers that will be deposited must have.

For this purpose, computer software was used with which the construction elements were first designed considering the manufacturing capabilities and the systems used in it. Then the layer definition process (sliced) was run on them (Fig. 2) considering fundamental parameters such as the thickness of the layer to be printed and the number of these. Once done, the trajectories of manufacturing equipment (paths definition) were defined to obtain those layers. Fig. 2 shows this definition of layers and printing paths for the pillar and beam.
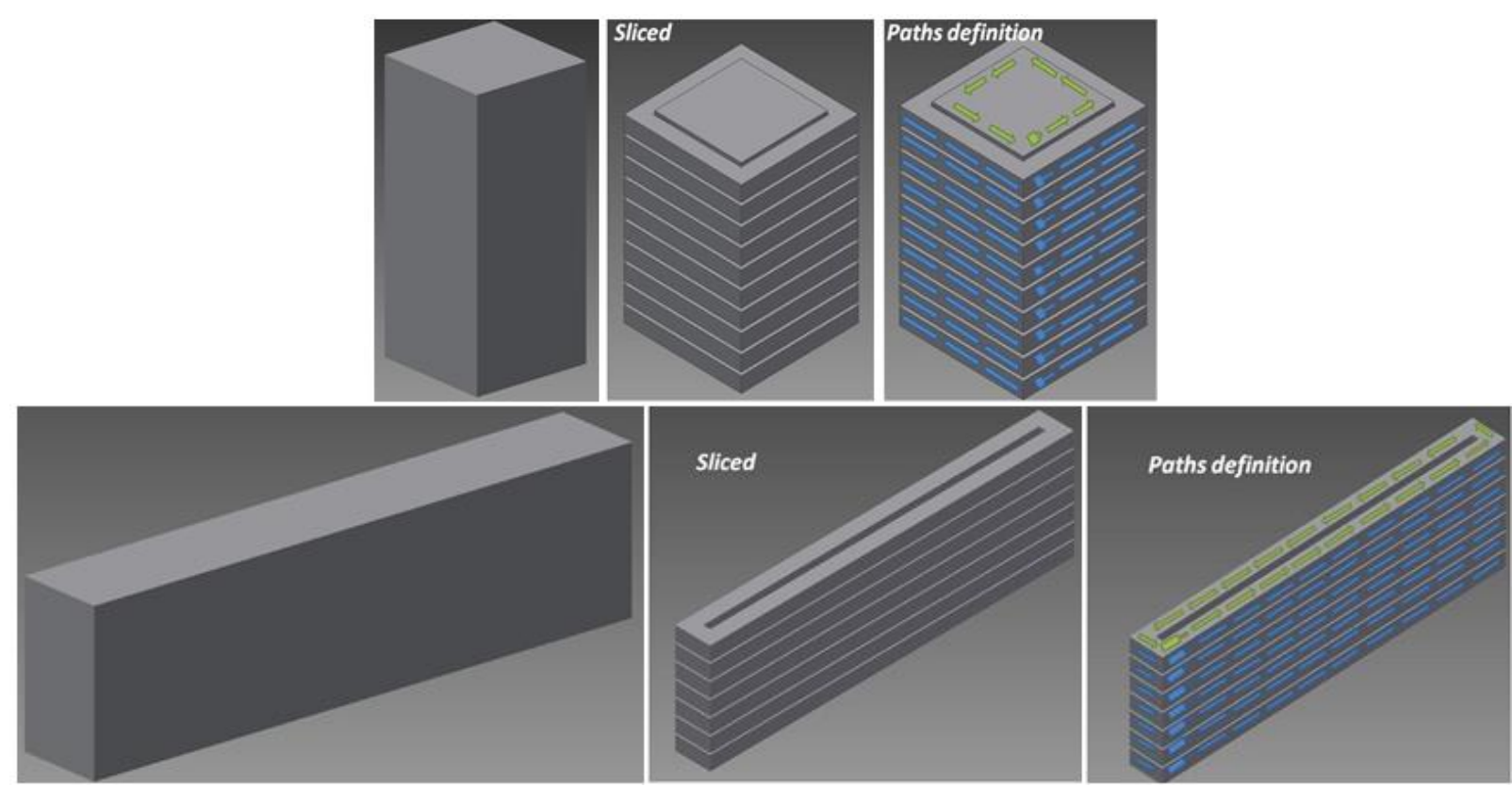

Fig. 2. Defining layers and print paths 


\begin{tabular}{|c|c|c|}
\hline $\begin{array}{l}\text { Ingeniería e Industria } \\
\text { Ind }\end{array}$ & $\begin{array}{c}\text { PRODUCTIVE PROCESSES BASED ON 3D PRINTING VERSUS } \\
\text { CONVENTIONAL METHODOLOGIES: A COMPARATIVE ANALYSIS IN } \\
\text { THE CONSTRUCTION SECTOR }\end{array}$ & $\begin{array}{r}\text { CONSTRUCTION } \\
\text { TECHNOLOGY }\end{array}$ \\
\hline RESEARCH ARTICLE & $\begin{array}{l}\text { José Manuel Mesa Fernández, Juan Carlos Piquero Camblor, Marina Díaz } \\
\text { Piloñeta, Henar Morán Palacios }\end{array}$ & Additive Manufacturing \\
\hline
\end{tabular}

The files generated in the previous process of layer definition and path printing are introduced into the specific software of the Kuka robotic cell to perform a virtual simulation of the manufacturing procedure that was carried out (Fig. 3). This simulation is very useful because it allows check for deviations or errors to correct both paths defined as movements that the robotic system performs to achieve.

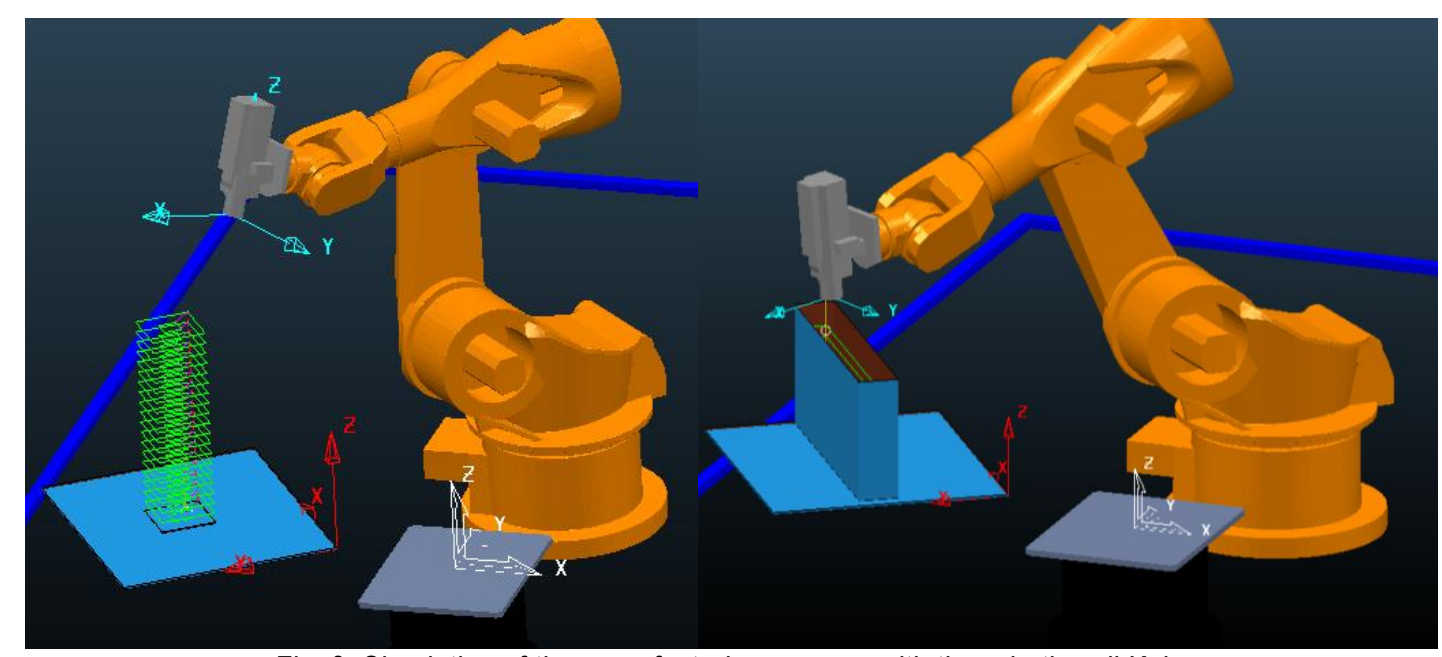

Fig. 3. Simulation of the manufacturing process with the robotic cell Kuka

Once it was verified that there were no deviations or errors in the generation of layers and trajectories, a pillar-shaped structure with a square base of 400 millimeters per side and an approximate height of 900 millimeters was manufactured by printing 16 layers of material with an approximate thickness of 55 millimetres. Printing began making the inside or core of the pillar, then perform printing its periphery to finished dimensions.

Secondly (Fig. 4), a rectangular base beam-shaped structure was manufactured, with dimensions of approximately 400 millimeters high, 200 millimeters wide and 1,300 millimeters long. The manufacturing process was carried out by printing 7 layers of approximately 55 millimeters thick.

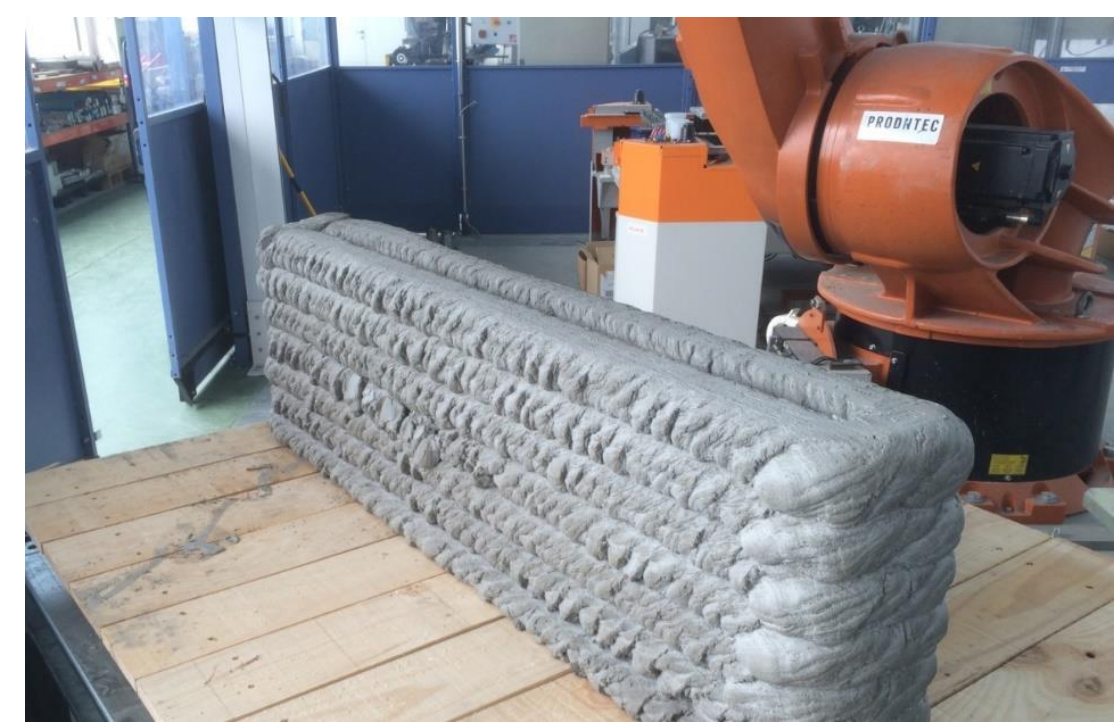

Fig. 4. 3D printing on concrete of the beam.

During the printing process of the structures, several stops were made in the deposition of the material to achieve the necessary level of setting for the correct support of the following layers. 


\begin{tabular}{|c|c|c|}
\hline $\begin{array}{l}\text { Ingeniería e Industria } \\
\text { Ind }\end{array}$ & $\begin{array}{c}\text { PRODUCTIVE PROCESSES BASED ON 3D PRINTING VERSUS } \\
\text { CONVENTIONAL METHODOLOGIES: A COMPARATIVE ANALYSIS IN } \\
\text { THE CONSTRUCTION SECTOR }\end{array}$ & $\begin{array}{r}\text { CONSTRUCTION } \\
\text { TECHNOLOGY }\end{array}$ \\
\hline RESEARCH ARTICLE & $\begin{array}{l}\text { José Manuel Mesa Fernández, Juan Carlos Piquero Camblor, Marina Díaz } \\
\text { Piloñeta, Henar Morán Palacios }\end{array}$ & Additive Manufacturing \\
\hline
\end{tabular}

\section{RESULTS}

Table 1 compares the process time, staff involved, material volume and formwork material for elements made by conventional construction process and by additive manufacturing. As can be seen, the manufacturing times of the additive manufacturing process are far (13 and 14 minutes for pillar and beam respectively) from those obtained by conventional manufacturing methods (120 and 129 minutes).

\begin{tabular}{|c|c|c|}
\cline { 2 - 3 } \multicolumn{1}{c|}{} & Conventional process & $\begin{array}{c}\text { Additive } \\
\text { manufacturing }\end{array}$ \\
\hline Pillar & & 13 \\
\hline Processing time (minutes) & 120 & 0,5 \\
\hline Staff involved (operators) & 2 & 316 \\
\hline Material volume (m3) & 316 & 0 \\
\hline Formwork material (kilograms) & 307 & 14 \\
\hline Beam & & 0,5 \\
\hline Processing time (minutes) & 129 & 158 \\
\hline Staff involved (operators) & 2 & 0 \\
\hline Material volume (m3) & 158 & 153 \\
\hline Formwork material (kilograms) & 153 . & \\
\hline Table & & \\
\hline
\end{tabular}

Table 1: Comparative data between conventional process and additive manufacturing

The volume of material used in both cases is identical, while obviously no formwork material is used in the additive process and the staff involved is significantly less. On the other hand, by means of a process speed test, the maximum and minimum admissible speeds were checked and evaluated so that the 3D printing process could be executed effectively, that is, being able to print parts in mortar / concrete without failures. Different tests were carried out where the amount of water added to the material was varied, as well as the material pumping and printing / movement speeds of the Cartesian system itself designed for this purpose. Additionally, during such tests, different impression material layer configurations were tested, varying their width and constituent height. In this test process, the layer configurations were established to be feasible considering two fundamental requirements:

- The ratio of low slenderness in the layer, that is, that there were no great differences in the width-height ratio of the layer, so that it can be printed without generating a risk to its structural integrity in the form of collapse or collapse of it .

- The establishment of the speed limits acceptable by the printing system, both in terms of its own integrity and in terms of the integrity of the printed structures, and without material deficiencies due to excessive deposition speed.

In the test plan worked with layers $100 \times 40 \mathrm{~mm}, 100 \times 50 \mathrm{~mm}, 100 \times 60 \mathrm{~mm}, 100 \times 70 \mathrm{~mm}, 100 \times 80 \mathrm{~mm}$ and feed rates of between $(1 \mathrm{~m} / \mathrm{min})$ and maximum $(7 \mathrm{~m} / \mathrm{min})$, based on this different productivities and qualities were obtained. The following graph (Fig. 5) shows the productivity of the new large-scale 3D printing system based on these parameters: 


\begin{tabular}{|c|c|c|} 
PRODUCTIVE PROCESSES BASED ON 3D PRINTING VERSUS \\
CONVENTIONAL METHODOLOGIES: A COMPARATIVE ANALYSIS IN \\
THE CONSTRUCTION SECTOR \\
Ingeniería e Industria \\
RESEARCH ARTICLE
\end{tabular}

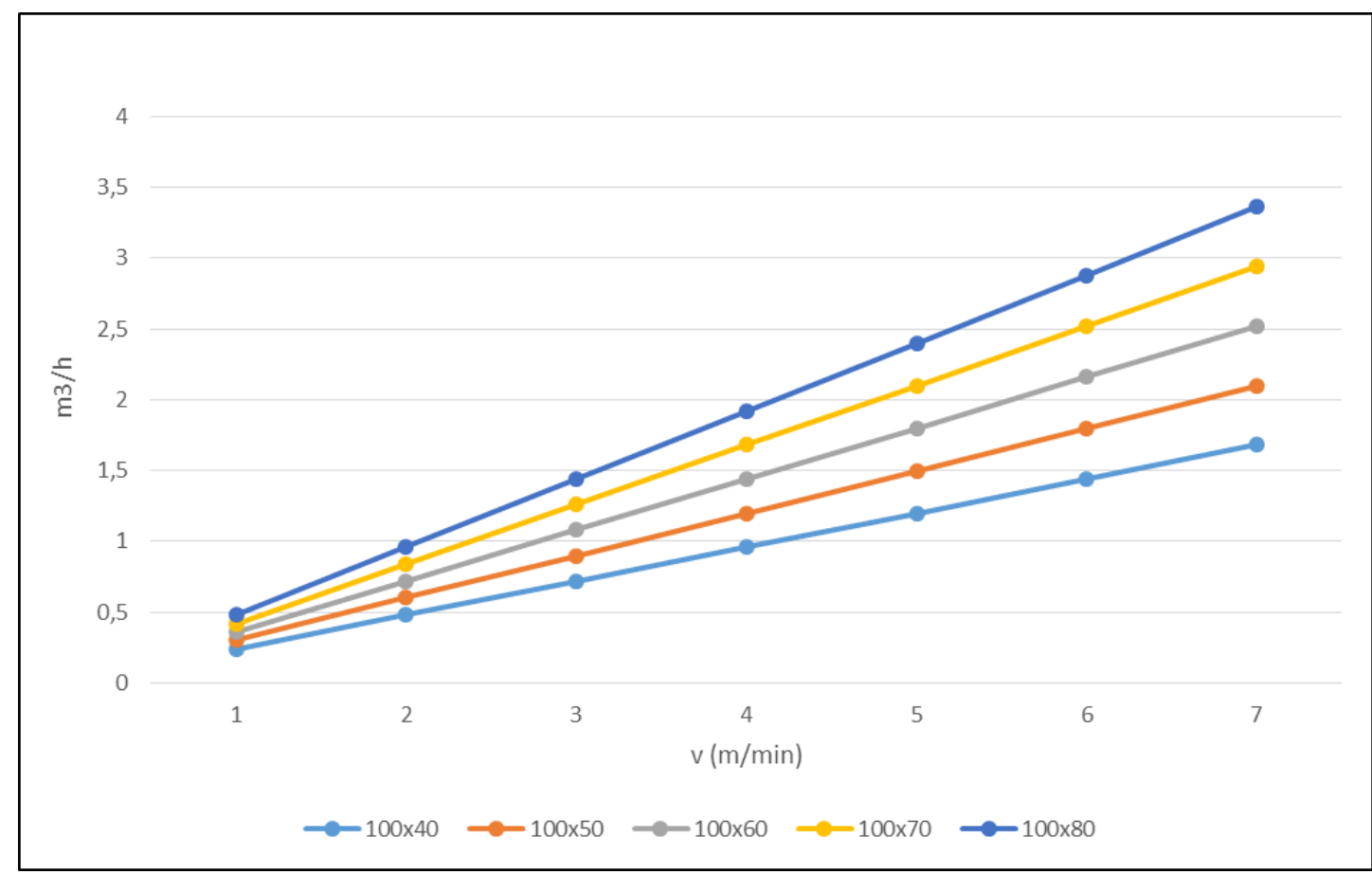

Fig. 5. Production rates $(\mathrm{m} 3 / \mathrm{h})$ based on the speed of advance of the robot (y-axis) and the layer dimensions.

The tested system therefore presents a clear reduction in process times (around $80 \%$ ), linked to the absence of formwork, short setting times and high productivity values that can reach more than $3 \mathrm{~m} 3 / \mathrm{h}$ with advance speeds of up to $420 \mathrm{~m} / \mathrm{h}$ with layers of up to $100 \mathrm{x}$ 80 millimeters.

Finally, with the aim of evaluating the quality of the resulting elements, the test and subsequent validation of the physical-mechanical properties of the manufactured elements (pillar and beam) were carried out by both methods. For this purpose, the following test methodology was established:

- Preparation of standard specimens: the procedure consisted of filling conventional $150 \times 150 \times 150 \mathrm{~mm}$. cube specimen molds, directly from the print head. This ensures that the concrete mix is deposited in the same way as it is done in the 3D printing process.

- Preparation of test specimens by 3D printing: after the generation of the standard specimens, we proceed to manufacture by additive manufacturing, a prismatic part with dimensions of approximately $700 \times 700 \times 400$ millimeters, thus generating a solid block. After the setting of the material for 24 hours, $150 \times 150 \times 150 \mathrm{~mm}$ specimens were extracted from the previously printed solid block by mechanical methods. The mechanical properties of which were compared with the data of the established pattern.

- $\quad$ Performing physical-mechanical: once prepared the test pieces, flexural strength tests were performed. In this line, rupture tests have been carried out at 30 hours and 7 days. Since the production process is fast, it is interesting to know the behavior of the samples in the short term, this being the reason for making breaks at 30 hours.

The results of the tests yielded values appropriate resistance but emphasized a reduction of around $25 \%$ compared to the resistance values thrown specimens obtained by conventional manufacturing methods (Fig. 6). This reduction is linked to the layer-by-layer material deposition process and the absence of a vibrating process, but the values obtained in the tests are, already 7 days, above the $25 \mathrm{MPa}$ required by regulations [30] for conventional concretes on 28 days. 


\begin{tabular}{|c|c|c|}
\hline $\begin{array}{l}\text { Ingeniería e Industria } \\
\text { Ind }\end{array}$ & $\begin{array}{c}\text { PRODUCTIVE PROCESSES BASED ON 3D PRINTING VERSUS } \\
\text { CONVENTIONAL METHODOLOGIES: A COMPARATIVE ANALYSIS IN } \\
\text { THE CONSTRUCTION SECTOR }\end{array}$ & $\begin{array}{r}\text { CONSTRUCTION } \\
\text { TECHNOLOGY }\end{array}$ \\
\hline RESEARCH ARTICLE & $\begin{array}{l}\text { José Manuel Mesa Fernández, Juan Carlos Piquero Camblor, Marina Díaz } \\
\text { Piloñeta, Henar Morán Palacios }\end{array}$ & Additive Manufacturing \\
\hline
\end{tabular}

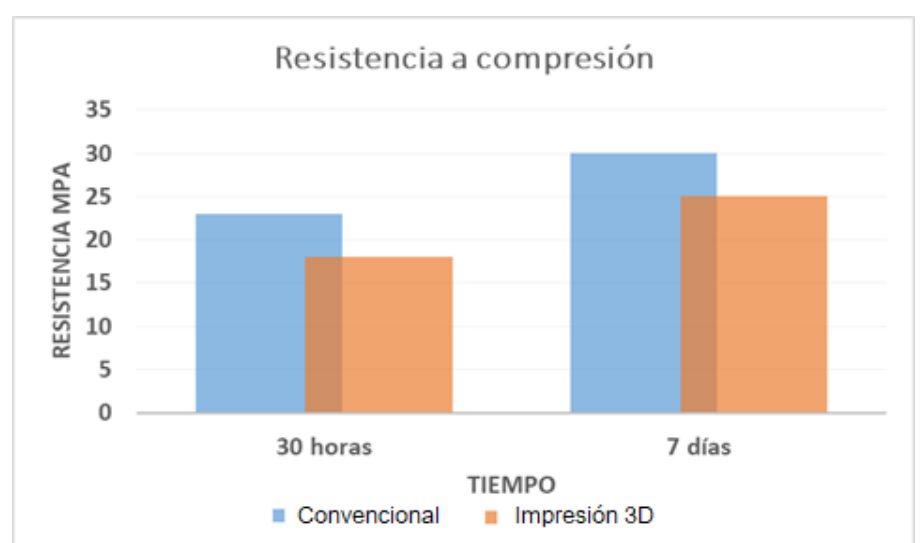

Fig. 6. Rupture of specimens obtained by printing (left) and traditional (right) method.

It should be noted that in the test specimen in the left image, obtained by additive manufacturing, the break follows a trend parallel to the manufacturing layers (Fig. 7), while, in those obtained in a conventional way, the break is predominant in the load application direction (vertical and transverse direction to it).

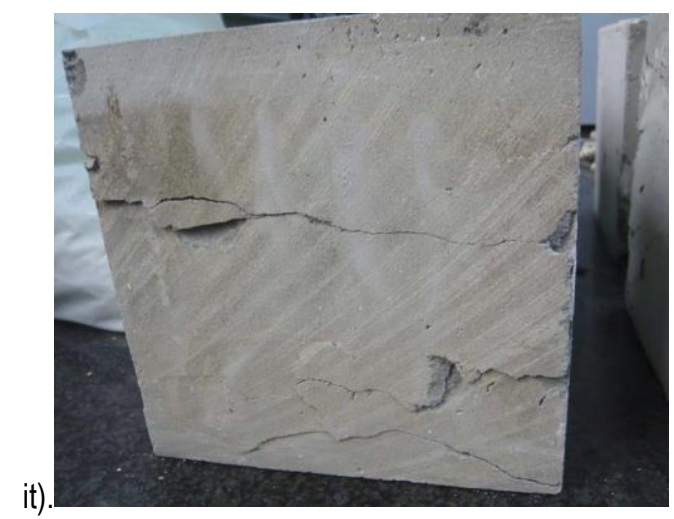

Fig. 7. Breakage of concrete specimen manufactured by $3 D$ printing.

\section{CONCLUSIONS}

The new proposed system represents a significant and necessary technological leap compared to current construction methods. The comparative study using common constructive elements carried out in this work allows draw the following conclusions regarding the use of additive manufacturing in construction:

- Reduce reliance on the human factor. After checking the design through simulation, the robot can perform the job through data taken directly from a digital file.

- It has been found that the elimination of formwork operations several advantages are obtained:

- A very significant reduction of manufacturing time, by eliminating the design, assembly, and removal time of the formwork.

- Less staff needed in the manufacturing process.

- Decreasing the costs associated with the auxiliary materials necessary.

- The risks associated with these operations.

- Materials (e.g. water content), layer definition and print paths, as well as print speed must be controlled for appropriate results.

- Improve the unit costs of the process, after the initial stage of development of the system, due to the significant reduction in the labor required, auxiliary materials and time spent for obtaining parts, will significantly reduce in the costs of the manufacturing process. 


\begin{tabular}{|l|c|}
\hline Ingeniería e Industria & $\begin{array}{c}\text { PRODUCTIVE PROCESSES BASED ON 3D PRINTING VERSUS } \\
\text { CONVENTIONAL METHODOLOGIES: A COMPARATIVE ANALYSIS IN } \\
\text { THE CONSTRUCTION SECTOR }\end{array}$ \\
\hline RESEARCH ARTICLE & $\begin{array}{c}\text { CONSTRUCTION } \\
\text { TECHNOLOGY }\end{array}$ \\
\hline
\end{tabular}

- The preliminary results of the tests carried out, in relation to the physical-mechanical properties of the manufactured elements, show adequate resistance values, although lower than those obtained by conventional means. It is necessary to deepen the future development of specific materials, as well as in the study of the effect of printing paths.

\section{BIBLIOGRAFÍA}

[1] J. Nazarko y E. Chodakowska, «Measuring Productivity of Construction Industry in Europe with Data Envelopment Analysis», Procedia Eng., vol. 122, pp. 204-212, ene. 2015, doi: http://dx.doi.org/10.1016/j.proeng.2015.10.026.

[2] S. Dixit, S. N. Mandal, J. V. Thanikal, y K. Saurabh, «Evolution of studies in construction productivity: A systematic literature review (2006-2017)», Ain Shams Eng. J., vol. 10, n. ${ }^{\circ}$ 3, pp. 555-564, sep. 2019, doi: http://dx.doi.org/10.1016/j.asej.2018.10.010.

[3] F. Craveiro, J. P. Duarte, H. Bartolo, y P. J. Bartolo, «Additive manufacturing as an enabling technology for digital construction: A perspective on Construction 4.0», Autom. Constr., vol. 103, pp. 251-267, jul. 2019, doi: http://dx.doi.org/10.1016/j.autcon.2019.03.011.

[4] T. Snyman y J. Smallwood, «Improving Productivity in the Business of Construction», Procedia Eng., vol. 182, pp. 651-657, ene. 2017, doi: http://dx.doi.org/10.1016/j.proeng.2017.03.175.

[5] B. García de Soto et al., «Productivity of digital fabrication in construction: Cost and time analysis of a robotically built wall», Autom. Constr., vol. 92, pp. 297-311, ago. 2018, doi: http://dx.doi.org/10.1016/j.autcon.2018.04.004.

[6] T. Bock, «The future of construction automation: Technological disruption and the upcoming ubiquity of robotics», Autom. Constr., vol. 59, pp. 113-121, nov. 2015, doi: http://dx.doi.org/10.1016/j.autcon.2015.07.022.

[7] I.-F. Häfliger et al., «Buildings environmental impacts' sensitivity related to LCA modelling choices of construction materials», J. Clean. Prod., vol. 156, pp. 805-816, jul. 2017, doi: http://dx.doi.org/10.1016/j.jclepro.2017.04.052.

[8] J. A. Bamgbade, A. M. Kamaruddeen, y M. N. M. Nawi, «Towards environmental sustainability adoption in construction firms: An empirical analysis of market orientation and organizational innovativeness impacts», Sustain. Cities Soc., vol. 32, pp. 486495, jul. 2017, doi: http://dx.doi.org/10.1016/j.scs.2017.04.015.

[9] A. Zutshi y A. Creed, «An international review of environmental initiatives in the construction sector», J. Clean. Prod., vol. 98, pp. 92-106, jul. 2015, doi: http://dx.doi.org/10.1016/j.jclepro.2014.06.077.

[10] S. H. Ghaffar, J. Corker, y M. Fan, «Additive manufacturing technology and its implementation in construction as an ecoinnovative solution», Autom. Constr., vol. 93, pp. 1-11, sep. 2018, doi: 10.1016/j.autcon.2018.05.005.

[11] I. Agustí-Juan, F. Müller, N. Hack, T. Wangler, y G. Habert, «Potential benefits of digital fabrication for complex structures: Environmental assessment of a robotically fabricated concrete wall», J. Clean. Prod., vol. 154, pp. 330-340, jun. 2017, doi: 10.1016/j.jclepro.2017.04.002.

[12] R. Liu, Z. Wang, T. Sparks, F. Liou, y J. Newkirk, «13 - Aerospace applications of laser additive manufacturing», en Laser Additive Manufacturing, M. Brandt, Ed. Woodhead Publishing, 2017, pp. 351-371.

[13] H. H. Malik et al., «Three-dimensional printing in surgery: a review of current surgical applications», J. Surg. Res., vol. 199, n. ${ }^{\circ}$ 2, pp. 512-522, dic. 2015, doi: 10.1016/j.jss.2015.06.051.

[14] I. S. Yoo et al., «Model Factory for Additive Manufacturing of Mechatronic Products: Interconnecting World-class Technology Partnerships with Leading AM Players», Procedia CIRP, vol. 54, pp. 210-214, ene. 2016, doi: 10.1016/j.procir.2016.03.113.

[15] C. Weller, R. Kleer, y F. T. Piller, «Economic implications of 3D printing: Market structure models in light of additive manufacturing revisited», Int. J. Prod. Econ., vol. 164, pp. 43-56, jun. 2015, doi: http://dx.doi.org/10.1016/j.jpe.2015.02.020.

[16] P. Reeves, «ATKINS: Manufacturing a Low Carbon Footprint: Zero Emission Enterprise Feasability Study», presentado en 2nd International Conference on Additive Technologies (iCAT), 2008.

[17] J. Pegna, «Exploratory investigation of solid freeform construction», Autom. Constr., vol. 5, n. ${ }^{0}$ 5, pp. 427-437, feb. 1997, doi: http://dx.doi.org/10.1016/S0926-5805(96)00166-5.

[18] D. Hwang, B. Khoshnevis, D. Hwang, y B. Khoshnevis, «An Innovative Construction Process-Contour Crafting (CC)», ISARC Proc., vol. 2005 Proceedings of the 22nd ISARC, Ferrara, Italy, pp. 0-0, 2005.

[19] G. Cesaretti, E. Dini, X. De Kestelier, V. Colla, y L. Pambaguian, «Building components for an outpost on the Lunar soil by means of a novel 3D printing technology», Acta Astronaut., vol. 93, pp. 430-450, ene. 2014, doi: http://dx.doi.org/10.1016/j.actaastro.2013.07.034.

[20] R. A. Buswell, R. C. Soar, A. G. F. Gibb, y A. Thorpe, «Freeform Construction: Mega-scale Rapid Manufacturing for construction», Autom. Constr., vol. 16, n. ${ }^{\circ}$ 2, pp. 224-231, mar. 2007, doi: http://dx.doi.org/10.1016/j.autcon.2006.05.002.

[21] S. Lim, R. A. Buswell, T. T. Le, S. A. Austin, A. G. F. Gibb, y T. Thorpe, «Developments in construction-scale additive manufacturing processes», Autom. Constr., vol. 21, pp. 262-268, ene. 2012, doi: http://dx.doi.org/10.1016/j.autcon.2011.06.010. 


\begin{tabular}{|c|c|c|}
\hline PRODUCTIVE PROCESSES BASED ON 3D PRINTING VERSUS & \\
CONVENTIONAL METHODOLOGIES: A COMPARATIVE ANALYSIS IN & THE CONSTRUCTION SECTOR \\
Ingeniería e Industria & $\begin{array}{c}\text { CONSTRUCTION } \\
\text { TECHNOLOGY }\end{array}$ \\
\hline RESEARCH ARTICLE & $\begin{array}{c}\text { José Manuel Mesa Fernández, Juan Carlos Piquero Camblor, Marina Díaz } \\
\text { Piloñeta, Henar Morán Palacios }\end{array}$ \\
\hline
\end{tabular}

[22] A. Kazemian, X. Yuan, E. Cochran, y B. Khoshnevis, «Cementitious materials for construction-scale 3D printing: Laboratory testing of fresh printing mixture», Constr. Build. Mater., vol. 145, pp. 639-647, ago. 2017, doi: http://dx.doi.org/10.1016/j.conbuildmat.2017.04.015.

[23] N. Khalil, G. Aouad, K. El Cheikh, y S. Rémond, «Use of calcium sulfoaluminate cements for setting control of 3D-printing mortars», Constr. Build. Mater., vol. 157, pp. 382-391, dic. 2017, doi: http://dx.doi.org/10.1016/j.conbuildmat.2017.09.109.

[24] R. Duballet, O. Baverel, y J. Dirrenberger, «Classification of building systems for concrete 3D printing», Autom. Constr., vol. 83, pp. 247-258, nov. 2017, doi: http://dx.doi.org/10.1016/j.autcon.2017.08.018.

[25] D. D. Camacho et al., «Applications of Additive Manufacturing in the Construction Industry: A Prospective Review», ISARC Proc., pp. 246-253, jul. 2017.

[26] I. Krimi, Z. Lafhaj, y L. Ducoulombier, «Prospective study on the integration of additive manufacturing to building industryCase of a French construction company», Addit. Manuf., vol. 16, pp. 107-114, ago. 2017, doi: http://dx.doi.org/10.1016/j.addma.2017.04.002.

[27] F. Hamidi y F. Aslani, «Additive manufacturing of cementitious composites: Materials, methods, potentials, and challenges», Constr. Build. Mater., vol. 218, pp. 582-609, sep. 2019, doi: http://dx.doi.org/10.1016/j.conbuildmat.2019.05.140.

[28] A. Paolini, S. Kollmannsberger, y E. Rank, «Additive manufacturing in construction: A review on processes, applications, and digital planning methods», Addit. Manuf., vol. 30, p. 100894, dic. 2019, doi: http://dx.doi.org/10.1016/j.addma.2019.100894.

[29] «Celdas de fabricación | KUKA AG». [En línea]. Disponible en: https://www.kuka.com/es-es/productos-servicios/instalacionesde-producci\%C3\%B3n/celdas-de-fabricaci\%C3\%B3n-estandarizadas. [Accedido: 10-ene-2020].

[30] AENOR-ISO, «UNE-EN 12390-2 Ensayos de hormigón endurecido. Parte 2: Fabricación y curado de probetas para ensayos de resistencia.» 2009.

\section{ACKNOWLEDGMENTS}

This work has been carried out thanks to the participation of the companies Cementos Tudela Veguín S.A. and Digafer S.A.

This work was funded by the Science, Technology and Innovation Plan of the Principality of Asturias (Spain) Ref: FC-GRUPIN-IDI/2018/000225, which is part-funded by the European Regional Development Fund (ERDF)

\begin{tabular}{|c|c|c|}
\hline & $\begin{array}{c}\text { Publicaciones DYNA SL - c) Mazarredo n69-40 - 48009-BILBAO (SPAIN) } \\
\text { Tel }+34944237566-\text { www.revistadyna.com - email: dyna@revistadyna.com }\end{array}$ \\
\hline
\end{tabular}

